\title{
Therapeutic Efficacy of Kalpaamruthaa on Lipid Peroxidation and Antioxidant Status in Experimental Mammary Carcinoma in Rats
}

\author{
Vanu Ramkumar Ramprasath, ${ }^{a}$ Babu Suresh Kumar, ${ }^{a}$ Palanivelu Shanthi, ${ }^{b}$ \\ and Panchanatham Sachdanandam*,a \\ ${ }^{a}$ Department of Medical Biochemistry and ${ }^{b}$ Department of Pathology, DR. A. L. Mudaliar Post- Graduate Institute of Basic Medical \\ Sciences, University of Madras, Taramani Campus, Chennai - 600 113, India
}

(Received August 9, 2006; Accepted September 3, 2006)

\begin{abstract}
There has been a growing interest in studying the role played by lipid peroxidation and antioxidant status in breast cancer. Free radicals are found to be involved in both initiation and promotion of multistage carcinogenesis. In the present study, effects of Kalpaamruthaa (KA), a modified Siddha preparation on the levels of lipid peroxides (LPO) and status of antioxidants in several tissues were studied in mammary carcinoma rats. The levels of reactive oxygen species (ROS) were also measured in the control and experimental animals. A significant increase in the levels of LPO, ROS and a decreased levels of antioxidants observed in mammary carcinoma bearing rats were found to be reverted back to near normal levels on treatment with KA. Simultaneous treatment with KA showed more effect than post treatment with KA. Drug control animals showed no significant changes in the levels of ROS when compared with control animals. These results suggest that the free radical mediated damage during mammary carcinoma could have been controlled by KA by its free radical quenching and antioxidative potential. The above results also show that KA exert its anticancer effect on the development of breast cancer.
\end{abstract}

Key words — mammary carcinoma, antioxidant, lipid peroxides, reactive oxygen species

\section{INTRODUCTION}

In breast cancer, generation of reactive oxygen species (ROS) is recognized to induce oxidative DNA damage and neoplastic transformation. Of late, ROS are being increasingly implicated in breast cancer development. ${ }^{1)}$ Moreover, the ROS-induced oxidative damage causes a decrease in the efficiency of antioxidant defense mechanism. In recent years, there has been a growing interest in studying the role played by lipid peroxides and antioxidant status. Proper balance between LPO and antioxidants should be maintained in the cell because of their potential importance in the pathogenesis of various pathologic diseases including cancer. Neoplastic cells may sequester essential antioxidants from circulation to supply the demands of growing tumour. Oxidative stress arises when there is an imbalance

\footnotetext{
*To whom correspondence should be addressed: Department of Medical Biochemistry, DR. A. L. Mudaliar Post- Graduate Institute of Basic Medical Sciences, University of Madras, Taramani Campus, Chennai - 600 113, India. Tel.: +91-4424925861; Fax: +91-44-24926709; E-mail: psachdanandam2000@ yahoo.co.in
}

between oxygen free radicals formation and scavenging by antioxidants. Excess generation of oxygen free radicals can cause oxidative damage to biomolecules resulting in LPO, mutagenesis and carcinogenesis. Oxygen free radicals-induced lipid peroxidation has been implicated in neoplastic transformation. ${ }^{2)}$

ROS such as superoxide anion radical $\left(\mathrm{O}_{2}^{--}\right)$, hydroxyl radical $\left(\mathrm{OH}^{*}\right)$ and hydrogen peroxide $\left(\mathrm{H}_{2} \mathrm{O}_{2}\right)$ are produced in aerobic metabolism. ${ }^{3)}$ Previous studies have demonstrated the involvement of ROS in breast cancer patients. ${ }^{4)}$

To control the overproduction of ROS, the cells protect themselves against oxidative damage by antioxidant detoxifying mechanisms that help to lower ROS concentrations in the body. Different antioxidant systems including nonenzymatic antioxidants such as reduced glutathione (GSH), vitamins $\mathrm{C}$ and $\mathrm{E}$ and various antioxidant enzymes such as Superoxide dismutase, Catalase, Glutathione peroxidase and Gulutathione-s- transferase act against free radical concentration and attacks. The sensitivity of the cell to ROS is attenuated by an array of enzymic and nonenzymic antioxidants. Superoxide dismutase 
(SOD) catalyses the dismutation of the $\mathrm{O}_{2}{ }^{-}$into $\mathrm{H}_{2} \mathrm{O}_{2}{ }^{5)} \mathrm{H}_{2} \mathrm{O}_{2}$ is metabolized by catalase and glutathione peroxidase (GPx) to form water. Catalase is an enzyme found in virtually all aerobic cells that under certain conditions can play a critical role in detoxifying $\mathrm{H}_{2} \mathrm{O}_{2}$ in tissues. GPx reduces $\mathrm{H}_{2} \mathrm{O}_{2}$ and organic peroxides (ROO) while oxidizing GSH. Oxidized glutathione (GSSG) is reduced back to GSH by glutathione reductase (GR) in the presence of NADPH. ${ }^{6}$ GSH in conjunction with GPx, plays a central role in the defense against free radicals, peroxides and a wide range of xenobiotics and carcinogens. ${ }^{7)}$

The erythrocytes are particularly vulnerable to oxidative damage due to continuous exposure to high oxygen tension as well as the presence of large amounts of iron, a potent catalyst for oxygen free radical production and polyunsaturated fatty acids (PUFA), major targets for peroxidation. ${ }^{8)}$ The normal erythrocyte is, however, resistant to oxidative damage, because it is rich in SOD, catalase (CAT), GSH, GPx, glutathione S-transferase (GST) and vitamin E. The plasma is also richly endowed with aqueous radical trapping antioxidants. ${ }^{7)}$ Low levels of essential antioxidants in the circulation have been found to be associated with an increased risk of cancer. ${ }^{9)}$

Kalpaamruthaa (KA) is a modified Siddha formulation which contains Semecarpus anacardium Linn. nut milk extract (SA), dried fruit powder of Emblica officinalis (EO) and honey. The component study of KA reveals the presence of flavonoids, ascorbic acid, polyphenols, tannins, sugars, sterols, etc. Dose dependant study of KA suggested the effective dosage level to be at $300 \mathrm{mg} / \mathrm{kg}$ body weight. ${ }^{10)}$ Semecarpus anacardium Linn. (Family: anacardiaceae) is commonly called as marking nut. ${ }^{11)}$ From the phytochemical studies of Siddha preparation of Semecarpus anacardium nut extract from our laboratory, reported by Vijayalakshmi et al., ${ }^{12)}$ it was found to contain phenols, flavonoids and carbohydrates. Further analysis revealed the presence of iron, copper, sodium, calcium and aluminium in traces. A number of pharmacological properties such as anticancer, ${ }^{13,14)}$ antirheumatic effects ${ }^{15,16)}$ and effectiveness against hepatocellular carcinoma ${ }^{17)}$ have been reported on SA. Emblica officinalis (syn: Phyllanthus emblica; family: Euphorbiaceae) commonly known as amla have been used in the treatment of cancer. It also possesses antibacterial, anti-inflammatory ${ }^{18)}$ properties. SA and EO have also been demonstrated to possess a strong free radical and antioxidative potential against mammary carcinoma. ${ }^{13,19)}$ Mahmud et al. ${ }^{20)}$ reported that the supplementation of Emblica officinalis combats cytotoxicity and has protective effect against chemical carcinogenesis. Honey has been reported to promote cell death and inhibit cancer cell growth. ${ }^{21)}$ Ascorbic acid, an important constituent of EO have been shown to prevent cancer. ${ }^{22}$ Hence, in the present study, the effects of KA on the alterations in the lipid peroxides and antioxidant status caused mammary carcinoma were investigated.

\section{MATERIALS AND METHODS}

Animals — Female albino Sprague-Dawley rats, 50-55 days, were obtained from the National Institute of Nutrition, Hyderabad, and maintained at $30^{\circ} \mathrm{C}$ (approx.) on a $12 \pm 1 \mathrm{hr}$ day-night rhythm. The rats were fed with commercial rat feed supplied by $\mathrm{M} / \mathrm{s}$ Hindustan lever Ltd. Mumbai India under the trade name Gold Mohur rat feed. Food and water were given ad libitum.

Animal Model: The rats were divided into five groups with six animals in each group and were given the dose regimen as follows. Group I: Control animals, Group II: Breast cancer was induced in overmight fasted animals by a single dose of 7,12 Di methyl benz(a)anthracene (DMBA) in olive oil $(25 \mathrm{mg} / \mathrm{kg}$ body weight) by gastric intubation. After six weeks, adenocarcinoma was confirmed by histologic examination. Group III: Breast cancer induced animals (as in Group II) but in addition, after three months, treatment was started orally with Kalpaamruthaa ( $300 \mathrm{mg} / \mathrm{Kg}$ body weight/day) dissolved in $0.5 \mathrm{ml}$ of olive oil and continued for 48 days daily by gastric intubation. Group IV: Mammary carcinoma was induced (as in Group II) but in addition, treatment was started from the day of induction orally with Kalpaamruthaa $(300 \mathrm{mg} / \mathrm{Kg}$ body weight/day) dissolved in $0.5 \mathrm{ml}$ of olive oil and continued for 48 days daily by gastric intubation. Group V: Drug treated control, the drug KA $(300 \mathrm{mg} /$ $\mathrm{kg}$ body wt) was administered to control animals for 48 days by intubation.

The study has got the ethical committee clearance and the experimental animals were handled according to the University and Institutional Legislation, regulated by the Committee for the Purpose of Control and Supervision of Experiments on Animals (CPCSEA), Ministry of Social Justice and Empowerment, Government of India.

Animals were weighed, explored by inspection 
and palpation and the two major and perpendicular diameters of each were measured with a caliper.

Tumour Volume: Total volume was measured using the formula $v=4 / 3 \times \pi \times\{(\mathrm{d} 1) / 2\} \times\{(\mathrm{d} 2 /$ 2)\}, where $d 1$ and $d 2$ are the two diameter of the (d1 $>\mathrm{d} 2$ ). At sacrifice, the volume of each was calculated using its three diameters: $v=4 / 3 \times \pi \times\{(\mathrm{d} 1) /$ 2) $X\{(\mathrm{~d} 2 / 2)\}-\{(\mathrm{d} 3 / 2)\}$.

After the experimental period, the animals were sacrificed by cervical decapitation. Breast tissues, liver and kidney were immediately excised from the animals and washed well with ice-cold saline and homogenized in Tris-HCI buffer $(0.1 \mathrm{M}, \mathrm{pH}$ 7.4). Blood was also collected for further analyses.

Biochemical Assays — The following parameters were estimated in control and experimental animals. Erythrocyte membrane was isolated according to the method of Dodge et al ${ }^{23)}$ Tissue lipid peroxides was estimated by the method of Devasagayam and Tarachand ${ }^{24)}$ using malondialdehyde as standard. Plasma lipid peroxide level was estimated by the method of Yagi ${ }^{25)}$ where the results were expressed as nmoles of malondialdehyde (MDA) formed/min/ $\mathrm{mg}$ protein. Superoxide dismutase was determined by the method of Marklund and Marklund. ${ }^{26)}$ The degree of inhibition of the autoxidation of pyrogallol at an alkaline $\mathrm{pH}$ by SOD was used as a measure of the enzyme activity. Catalase and glutathione peroxidase activities were estimated by the method of Sinha et al.,${ }^{27)}$ and Rotruck et al. ${ }^{28)}$ respectively. Catalase decomposes $\mathrm{H}_{2} \mathrm{O}_{2}$ to water and hence, the activity of CAT was measured from the amount of $\mathrm{H}_{2} \mathrm{O}_{2}$ consumed per minute per mg protein. GPx is expressed as micro grams of glutathione utilized per minute per mg protein at $37^{\circ} \mathrm{C}$. The activity of glutathione-S-transferase was assayed by the method of Habig et al. ${ }^{29)}$ The enzyme activity is expressed as $\mu$ moles of chloro 2,4,dinitrobenzene (CDNB) formed $/ \mathrm{min} / \mathrm{mg}$ protein. GSH was determined by the method of Moron et al.,$^{30)}$ which was based on the reaction of GSH with 5,5-dithiobis-2-nitrobenzoic acid (DTNB) to give a compound that absorbs at $412 \mathrm{~nm}$. Vitamin E was estimated by the method of Quaife and $\mathrm{Dju}^{31)}$ with slight modification by Baker and Frank. ${ }^{32)}$ Vitamin E level is expressed as $\mathrm{mg} / \mathrm{dl}$ for plasma and $\mathrm{mg} / \mathrm{g}$ wet tissue for breast tissue, liver and kidney. ${ }^{33)}$ Vitamin $\mathrm{C}$ was estimated by the method of Omaye et al. ${ }^{34)}$ Vitamin C level is expressed as $\mathrm{mg} / \mathrm{dl}$ for plasma and $\mathrm{mg} / \mathrm{g}$ wet tissue for breast tissue, liver and kidney. Protein content was measured by the method of Lowry et al. ${ }^{35)}$ ROS namely, Superoxide radical and $\mathrm{H}_{2} \mathrm{O}_{2}{ }^{36-38)}$ were also measured. Hydroxy radical was measured by their reaction (hydrogen substraction) from 2-deoxy ribose, resulting in the formation of thiobarbituric acid reacting species. Amount of hydroxyl radicals present in the cells were expressed in terms of MDA as $\mathrm{nmol} / 10^{12}$ cells. Superoxides were estimated, in which SOD was inhibited with diethyldithiocarbamate. For each sample, superoxide was measured as nitro blue tetrazolium (NBT) reduction in two sets of tubes. In one set of tubes, SOD was inhibited. The difference gave the superoxide radicals present at the time of assay. Hydrogen peroxide $\left(\mathrm{H}_{2} \mathrm{O}_{2}\right)$ was estimated by the method of Wolff. ${ }^{38)} \mathrm{H}_{2} \mathrm{O}_{2}$ oxidises ferrous ion to ferric ion selectively in dilute acid and resultant ferric ion can be determined by sensitive dye xylenol orange. OCresolsulfonaphthalein $3^{\prime}, 3^{\prime}$-bis methylimino diacetic acid which is highly sensitive to ferric ion to form a blue-purple complex measured at $540 \mathrm{~nm}$. The hydrogen peroxide levels were expressed as $\mu$ moles $/ 10^{12}$ cells.

Statistical Analysis — Results were presented as Mean \pm S.D. of six rats. The results were statistically analysed using one-way analysis of variance (ANOVA) followed by the post hoc Student's Neuman Keuls test for multiple comparisons using Statistical Package for Social Sciences (SPSS) computer package. Values of $p<0.05$ was considered to be significant.

\section{RESULTS AND DISCUSSION}

Table 1 depicts the body weight, tumour weight and tumour volume changes of the control and experimental animals. Initially, there was no significant change in the body weight of the control and experimental animals. Finally, the bosy weight of mammary carcinoma bearing animals were significantly $(p<0.05)$ reduced when compared to control animals. In contrast, the post induction treated rats showed an $(p<0.05)$ increase in their body weight when compared to mammary carcinoma bearing animals. The simultaneously treated animals also showed an increase in the body weight when compared to mammary carcinoma animals. Drug control animals showed an increase in their body weight but not to significant levels when compared to normal healthy animals.

In mammary carcinoma bearing animals, the sharp decline in their body weight may be due to the cancer cachexia which results in progressive loss of 
Table 1. Effect of KA on the Levels of Body Weight, Tumour Weight and Tumour Volume of Control and Experimental Animals

\begin{tabular}{|c|c|c|c|c|c|}
\hline Parameter & $\begin{array}{l}\text { Group-I } \\
\text { (Control) }\end{array}$ & $\begin{array}{l}\text { Group-II } \\
\text { (Tumour induced) }\end{array}$ & $\begin{array}{l}\text { Group-III } \\
\text { (Tumour induced + } \\
\text { post treated) }\end{array}$ & $\begin{array}{l}\text { Group-IV } \\
\text { (Tumour induced } \\
+ \text { simultaneous treated) }\end{array}$ & $\begin{array}{c}\text { Group-V } \\
\text { (Drug control) }\end{array}$ \\
\hline Body weight (gm) & $279.81 \pm 21.84$ & $237.43 \pm 20.18^{*, a)}$ & $251.79 \pm 21.05^{*, b)}$ & $265.57 \pm 21.25^{*, b, c), \mathrm{NS}}$ & $284.17 \pm 25.08^{a), \mathrm{NS}}$ \\
\hline Tumour weight (gm) & - & $3.67 \pm 0.24$ & $1.79 \pm 0.11^{*, b)}$ & $\left.1.21 \pm 0.08^{*}, b, c\right)$ & - \\
\hline Tumour volume (ml) & - & $30.67 \pm 3.0$ & $24.11 \pm 2.2^{*, b)}$ & $19.74 \pm 1.5^{*, b, c)}$ & - \\
\hline
\end{tabular}

The values are expressed as mean \pm S.D. of six animals. Comparisons were made between: $a$ ) When compared with control animals. $b$ ) When compared with mammary carcinoma induced animals. $c$ ) When compared with mammary carcinoma + post KA treated animals. * denotes significance at the level of $p<0.05$. NS denotes non-significance at the level of $p<0.05$.

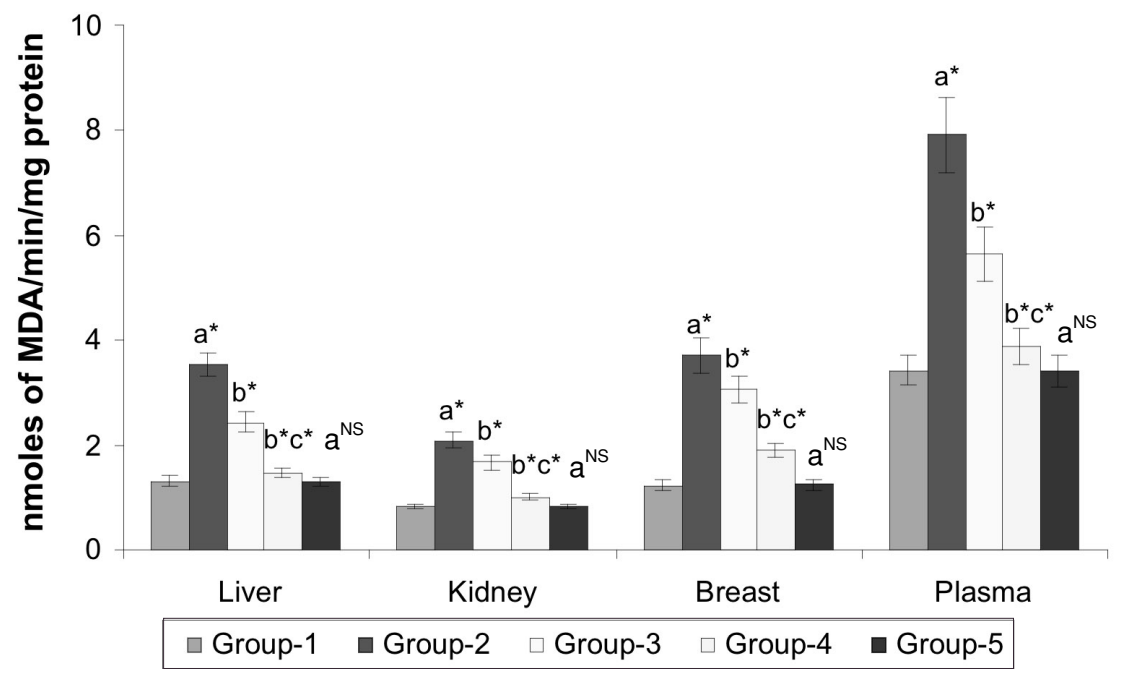

Fig. 1. Effect KA on the Levels of Lipid Peroxides in Control and Experimental Animals

The values are expressed as mean \pm S.D. of six animals. Comparisons were made between: a; When compared with control animals. b; When compared with mammary carcinoma induced animals. c; When compared with mammary carcinoma + post KA treated. * denotes significance at the level of $p<0.05$. NS denotes non-significance at the level of $p<0.05$.

body weight, which is mainly accounted by wasting of host body compartments such as a skeletal muscle and adipose tissue. Weight loss and tissue wasting are observed in cancer patients implies poor prognosis and shorter survival time for cancer patients. ${ }^{39}$ ) Pain et al., ${ }^{40)}$ reported that the drop in body weight results due to the less amount of food intake and /or absorption, which contributes to muscle wasting in tumour cachexia. In post treated and simultaneous treated groups of animals, the significant increase in body weight indicates the antineoplastic property of the drug. Drug control animals did not show any significant variations. Drug does not exert any evil side effect or toxic symptoms indicating its non-toxic nature.

There was a considerable tumour progression in the untreated animals when compared to the treated animals which might be due to the tumour proliferation of the cancer cells. In drug treated animals, the tumour did not disappear totally, but a significant regression was found when compared to untreated rats showing the inhibitory action of the drug on tumour growth. Flavonoids are reported to have inhibitory action on various stages of tumour development in animal studies. ${ }^{41)}$

Fig. 1 shows the levels of lipid peroxides in the breast, liver, kidney and serum of control and experimental groups of rats. A significant increase $(p<0.05)$ in the lipid peroxides level was observed in the mammary carcinoma bearing animals when compared to control animals. Post-treated animals showed a significant $(p<0.05)$ decrease in the level of lipid peroxides when compared to diseased untreated animals. Simultaneous treated animals showed steep decrease in the level of lipid peroxides when compared with Group II and III animals. Drug control animals showed no significant changes in the level of the lipid peroxides when compared to 
Table 2. Effect of KA on the Activities of Enzymic Antioxidants in Liver of Control and Experimental Animals

\begin{tabular}{|c|c|c|c|c|c|}
\hline Parameter & $\begin{array}{l}\text { Group-I } \\
\text { (Control) }\end{array}$ & $\begin{array}{l}\text { Group-II } \\
\text { (Tumour induced) }\end{array}$ & $\begin{array}{l}\text { Group-III } \\
\text { (Tumour induced + } \\
\text { post KA treated) }\end{array}$ & $\begin{array}{l}\text { Group-IV } \\
\text { (Tumour induced + } \\
\text { simultaneous KA treated) }\end{array}$ & $\begin{array}{c}\text { Group-V } \\
\text { (Drug control) }\end{array}$ \\
\hline $\begin{array}{l}\text { Superoxide dismutase } \\
\text { (unit/min/mg protein) }\end{array}$ & $5.27 \pm 0.45$ & $2.69 \pm 0.21^{*, a)}$ & $4.02 \pm 0.37^{*, b)}$ & $4.82 \pm 0.42 * b, c)$ & $5.25 \pm 0.47^{a), \mathrm{NS}}$ \\
\hline $\begin{array}{l}\text { Catalase } \\
\mu \text { mol of } \mathrm{H}_{2} \mathrm{O}_{2} \\
\text { consumed } / \mathrm{min} / \mathrm{mg} \text { protein }\end{array}$ & $394.9 \pm 32.4$ & $207.1 \pm 16.5^{*, a)}$ & $271.6 \pm 24.8^{*, b)}$ & $327.3 \pm 27.1^{*, b, c)}$ & $394.5 \pm 36.4^{a), \mathrm{NS}}$ \\
\hline $\begin{array}{l}\text { Glutathione Peroxidase } \\
\mu \mathrm{g} \text { of GSH } \\
\text { consumed/min/mg protein }\end{array}$ & $32.71 \pm 2.65$ & $22.93 \pm 1.97^{*, a)}$ & $27.85 \pm 2.38^{*, b)}$ & $31.9 \pm 2.90^{*, b, c)}$ & $32.73 \pm 2.94^{a), \mathrm{NS}}$ \\
\hline $\begin{array}{l}\text { Glutathione-s- transferase } \\
\mu \mathrm{mol} \text { of CDNB } \\
\text { utilized/min/mg protein }\end{array}$ & $3.19 \pm 0.26$ & $1.73 \pm 0.11^{*, a)}$ & $2.45 \pm 0.21^{*, b)}$ & $3.01 \pm 0.24^{*, b, c)}$ & $3.21 \pm 0.28^{a), \mathrm{NS}}$ \\
\hline
\end{tabular}

Table 3. Effect of KA on the Activities of Enzymic Antioxidants in Kidney of Control and Experimental Animals

\begin{tabular}{|c|c|c|c|c|c|}
\hline Parameter & $\begin{array}{l}\text { Group-I } \\
\text { (Control) }\end{array}$ & $\begin{array}{l}\text { Group-II } \\
\text { (Tumour induced) }\end{array}$ & $\begin{array}{l}\text { Group-III } \\
\text { (Tumour induced + } \\
\text { post KA treated) }\end{array}$ & $\begin{array}{l}\text { Group-IV } \\
\text { (Tumour induced + } \\
\text { simultaneous KA treated) }\end{array}$ & $\begin{array}{c}\text { Group-V } \\
\text { (Drug control) }\end{array}$ \\
\hline $\begin{array}{l}\text { Superoxide dismutase } \\
\text { (unit/min/mg protein) }\end{array}$ & $3.90 \pm 0.33$ & $\left.2.61 \pm 0.22^{*}, a\right)$ & $3.02 \pm 0.29^{*, b)}$ & $3.64 \pm 0.31^{*, b, c)}$ & $3.88 \pm 0.34^{a,, \mathrm{NS}}$ \\
\hline $\begin{array}{l}\text { Catalase } \\
\mu \text { mol of } \mathrm{H}_{2} \mathrm{O}_{2} \\
\text { consumed/min/mg protein }\end{array}$ & $276.3 \pm 21.8$ & $143.4 \pm 11.8^{*, a)}$ & $199.7 \pm 15.6^{*, b)}$ & $253.5 \pm 20.4^{*, b, c}$ & $275.6 \pm 23.9^{a), \mathrm{NS}}$ \\
\hline $\begin{array}{l}\text { Glutathione Peroxidase } \\
\mu \mathrm{g} \text { of GSH } \\
\text { consumed/min/mg protein }\end{array}$ & $23.90 \pm 1.97$ & $13.73 \pm 1.10^{*, a)}$ & $18.81 \pm 1.51^{*, b)}$ & $27.03 \pm 2.08^{*, b, c)}$ & $23.9 \pm 2.15^{a), \mathrm{NS}}$ \\
\hline $\begin{array}{l}\text { Glutathione-s- transferase } \\
\mu \mathrm{mol} \text { of CDNB } \\
\text { utilized/min/mg protein }\end{array}$ & $2.57 \pm 0.19$ & $1.02 \pm 0.07^{*, a)}$ & $1.79 \pm 0.11^{*, b)}$ & $2.05 \pm 0.14^{*, b, c)}$ & $2.59 \pm 0.21^{a), \mathrm{NS}}$ \\
\hline
\end{tabular}

normal control animals.

Lipid peroxidation is regarded as one of the basic mechanism of cellular damage caused by free radicals. Free radicals react with lipid causing peroxidation resulting in release of products such as MDA, hydrogen peroxide $\left(\mathrm{H}_{2} \mathrm{O}_{2}\right)$ and hydroxyl radicals $(\mathrm{OH})$. ROS including $\mathrm{O}_{2}^{-}, \mathrm{H}_{2} \mathrm{O}_{2}$ and $\mathrm{OH}$ radicals play an important role in carcinogenesis. ${ }^{42)}$ Free radicals are involved in a wide variety of diseases, especially cancer. They cause lipid peroxidation of membrane lipids leading to cellular damage and derangement in membrane function and integrity.

Drug treated animals showed a significant $(p<$ 0.05 ) decrease in the lipid peroxide levels when com- pared to mammary carcinoma bearing animals. This may be due to free radical scavenging action of flavonoids, isoflavonoids and ascorbic acid present in the drug, "Kalpaamruthaa". Flavonoids possess free radical quenching activity and protect against lipid peroxidation which reduces lipid peroxidation by enhancing host detoxification system. ${ }^{43)}$

Tables 2-7 shows the activities of enzymic antioxidants like SOD, CAT, GPx, GST and levels of non-enzymic antioxidants like GSH, Vitamin C and Vitamin E in liver, kidney, breast tissue, hemolyasate and plasma of control and experimental animals, respectively. Cancer bearing animals showed a significant decrease $(p<0.05)$ in the activities of these 
Table 4. Effect of KA on the Activities of Enzymic Antioxidants in Breast of Control and Experimental Animals

\begin{tabular}{lccccc}
\hline \hline Parameter & $\begin{array}{c}\text { Group-I } \\
(\text { Control })\end{array}$ & $\begin{array}{c}\text { Group-II } \\
\text { (Tumour induced) }\end{array}$ & $\begin{array}{c}\text { Group-III } \\
\text { (Tumour induced }+ \\
\text { post KA treated) }\end{array}$ & $\begin{array}{c}\text { Group-IV } \\
\text { (Tumour induced }+ \\
\text { simultaneous KA treated) }\end{array}$ & $\begin{array}{c}\text { Group-V } \\
\text { (Drug control) }\end{array}$ \\
\hline $\begin{array}{l}\text { Superoxide dismutase } \\
\text { (unit/min/mg protein) }\end{array}$ & $10.91 \pm 0.98$ & $5.93 \pm 0.54^{*, a)}$ & $7.67 \pm 0.71^{*, b)}$ & $9.51 \pm 0.89^{*, b, c)}$ & $10.94 \pm 0.91^{a), \mathrm{NS}}$ \\
$\begin{array}{l}\text { Catalase } \\
\mu \text { mol of } \mathrm{H}_{2} \mathrm{O}_{2} \\
\text { consumed/min/mg protein }\end{array}$ & $50.75 \pm 4.76$ & $27.12 \pm 2.18^{*, a)}$ & $38.91 \pm 3.27^{*, b)}$ & $49.53 \pm 4.37^{*, b, c)}$ & $50.77 \pm 4.15^{a), \mathrm{NS}}$ \\
$\begin{array}{l}\text { Glutathione Peroxidase } \\
\mu \mathrm{g} \text { of GSH } \\
\text { consumed/min/mg protein } \\
\text { Glutathione-s- transferase } \\
\mu \text { mol of CDNB }\end{array}$ & $9.03 \pm 0.84$ & $3.12 \pm 0.27^{*, a)}$ & $6.07 \pm 0.58^{*, b)}$ & $8.35 \pm 0.77^{*, b, c)}$ & $9.01 \pm 0.85^{a), \mathrm{NS}}$ \\
utilized/min/mg protein & $3.41 \pm 0.26$ & $1.17 \pm 0.08^{*, a)}$ & $\left.2.19 \pm 0.16^{*, b}\right)$ & $3.01 \pm 0.24^{*, b, c)}$ & $3.42 \pm 0.30^{a), \mathrm{NS}}$ \\
\hline
\end{tabular}

Units of SOD defined as the amount of enzyme required to bring about 50\% inhibition of the auto-oxidation of Pyrogallol. The values are expressed as mean \pm S.D. of six animals. Comparisons were made between: $a$ ) When compared with control animals. $b$ ) When compared with mammary carcinoma induced animals. $c$ ) When compared with mammary carcinoma + post KA treated. $*$ denotes significance at the level of $p<$ 0.05 . NS denotes non-significance at the level of $p<0.05$.

Table 5. Effect of KA on the Activities of Enzymic Antioxidants in Hemolysate of Control and Experimental Animals

\begin{tabular}{|c|c|c|c|c|c|}
\hline Parameter & $\begin{array}{l}\text { Group-I } \\
\text { (Control) }\end{array}$ & $\begin{array}{c}\text { Group-II } \\
\text { (Tumour induced) }\end{array}$ & $\begin{array}{l}\text { Group-III } \\
\text { (Tumour induced + } \\
\text { post KA treated) }\end{array}$ & $\begin{array}{l}\text { Group-IV } \\
\text { (Tumour induced }+ \\
\text { simultaneous KA treated) }\end{array}$ & $\begin{array}{c}\text { Group-V } \\
\text { (Drug control) }\end{array}$ \\
\hline $\begin{array}{l}\text { Superoxide dismutase } \\
\text { (unit/min/mg protein) }\end{array}$ & $2.93 \pm 0.26$ & $1.21 \pm 0.10^{*, a)}$ & $1.95 \pm 0.14^{*, b)}$ & $2.63 \pm 2.10^{*, b, c)}$ & $2.91 \pm 0.25^{a), \mathrm{NS}}$ \\
\hline $\begin{array}{l}\text { Catalase } \\
\mu \text { mol of } \mathrm{H}_{2} \mathrm{O}_{2} \\
\text { consumed } / \mathrm{min} / \mathrm{mg} \text { protein }\end{array}$ & $47.12 \pm 4.52$ & $23.21 \pm 1.95^{*, a)}$ & $35.27 \pm 2.9^{*, b)}$ & $45.97 \pm 3.96^{*, b, c)}$ & $46.87 \pm 4.17^{a), \mathrm{NS}}$ \\
\hline $\begin{array}{l}\text { Glutathione Peroxidase } \\
\mu \mathrm{g} \text { of } \mathrm{GSH} \\
\text { consumed/min/mg protein }\end{array}$ & $16.07 \pm 1.18$ & $5.93 \pm 0.47^{*, a)}$ & $\left.11.00 \pm 0.94^{*, b}\right)$ & $15.57 \pm 1.19^{*, b, c)}$ & $16.03 \pm 1.37^{a), \mathrm{NS}}$ \\
\hline $\begin{array}{l}\text { Glutathione-s- transferase } \\
\mu \text { mol of CDNB } \\
\text { utilized/min/mg protein }\end{array}$ & $1.83 \pm 0.14$ & $0.61 \pm 0.04^{*, a)}$ & $0.98 \pm 0.07^{*, b)}$ & $1.43 \pm 0.11^{*, b, c)}$ & $1.83 \pm 0.12^{a), \mathrm{NS}}$ \\
\hline
\end{tabular}

antioxidants when compared to control animals. The post treated animals showed a significant $(p<0.05)$ increase in these enzyme antioxidants when compared to diseased untreated animals. The simultaneous treated animals showed a steep $(p<0.05)$ increase when compared with Group 2 and 3 animals. Drug control animals did not show any significant changes in the activities of enzymic and levels of nonenzymic antioxidants when compared to control animals. Table 8 shows the levels of ROS in hemolysate of control and experimental animals. Levels of ROS in hemolysate of mammary carcinoma bearing animals were found to be significantly $(p<0.05)$ increased when compared to control ani- mals. On administration of the drug (KA), the levels of ROS were found to be significantly $(p<0.05)$ decreased when compared to diseased animals. Simultaneous treatment with KA showed more effect than post treatment with KA. Drug control animals showed no significant changes in the levels of ROS when compared with control animals.

Oxidative stress resulting from an imbalance between proxidants and antioxidant status seems to play an important role in breast cancer. ${ }^{44)}$ Improper balance between prodution of ROS and antioxident defense system have been defined as oxidative stress in various pathologic condition. ${ }^{45)}$ Primary antioxidants such as SOD, GPx, CAT and GST protect the 
Table 6. Effect of KA on the Levels of Non-Enzymic Antioxidants in Liver and Kidney of Control and Experimental Animals

\begin{tabular}{|c|c|c|c|c|c|}
\hline Parameter & $\begin{array}{l}\text { Group-I } \\
\text { (Control) }\end{array}$ & $\begin{array}{l}\text { Group-II } \\
\text { (Tumour induced) }\end{array}$ & $\begin{array}{l}\text { Group-III } \\
\text { (Tumour induced + } \\
\text { post KA treated) }\end{array}$ & $\begin{array}{l}\text { Group-IV } \\
\text { (Tumour induced }+ \\
\text { simultaneous KA treated) }\end{array}$ & $\begin{array}{c}\text { Group-V } \\
\text { (Drug control) }\end{array}$ \\
\hline \multicolumn{6}{|c|}{ Liver } \\
\hline $\begin{array}{l}\text { GSH } \\
(\mu \mathrm{g} / \mathrm{mg} \text { protein })\end{array}$ & $4.61 \pm 0.41$ & $2.08 \pm 0.18^{*, a)}$ & $\left.3.01 \pm 0.23^{*}, b\right)$ & $3.57 \pm 0.31^{*, b, c)}$ & $4.59 \pm 0.40^{a), \mathrm{NS}}$ \\
\hline $\begin{array}{l}\text { Vit. C } \\
\text { (mg/g wet tissue) }\end{array}$ & $2.79 \pm 0.23$ & $\left.1.31 \pm 0.10^{*}, a\right)$ & $2.05 \pm 0.16^{*, b)}$ & $2.57 \pm 0.20^{*, b, c)}$ & $2.81 \pm 0.25^{a), \mathrm{NS}}$ \\
\hline $\begin{array}{l}\text { Vit. E } \\
\text { (mg/g wet tissue) }\end{array}$ & $2.38 \pm 0.19$ & $\left.1.07 \pm 0.09^{*}, a\right)$ & $1.72 \pm 0.13^{*, b)}$ & $2.01 \pm 0.16^{*, b, c)}$ & $2.40 \pm 0.20^{a), \mathrm{NS}}$ \\
\hline \multicolumn{6}{|c|}{ Kidney } \\
\hline $\begin{array}{l}\text { GSH } \\
(\mu \mathrm{g} / \mathrm{mg} \text { protein })\end{array}$ & $3.21 \pm 0.30$ & $\left.1.98 \pm 0.14^{*}, a\right)$ & $\left.2.59 \pm 0.19^{*}, b\right)$ & $3.03 \pm 0.26^{*, b, c)}$ & $3.22 \pm 0.28^{a), \mathrm{NS}}$ \\
\hline $\begin{array}{l}\text { Vit. C } \\
\text { (mg/g wet tissue) }\end{array}$ & $2.15 \pm 0.13$ & $1.02 \pm 0.08 *, a)$ & $\left.1.58 \pm 0.12^{*}, b\right)$ & $\left.2.01 \pm 0.17^{*}, b, c\right)$ & $2.16 \pm 0.19^{a), \mathrm{NS}}$ \\
\hline $\begin{array}{l}\text { Vit. E } \\
\text { (mg/g wet tissue) }\end{array}$ & $1.75 \pm 0.13$ & $\left.0.61 \pm 0.05^{*}, a\right)$ & $\left.1.19 \pm 0.09^{*}, b\right)$ & $\left.1.51 \pm 0.10^{*}, b, c\right)$ & $1.76 \pm 0.12^{a), \mathrm{NS}}$ \\
\hline
\end{tabular}

The values are expressed as mean \pm S.D. of six animals. Comparisons were made between: $a$ ) When compared with control animals. $b$ ) When compared with mammary carcinoma induced animals. $c$ ) When compared with mammary carcinoma + post KA treated. * denotes significance at the level of $p<0.05$. NS denotes non-significance at the level of $p<0.05$.

Table 7. Effect of KA on the Levels of Non-Enzymic Antioxidant in Plasma and Breast Tissue of Control and Experimental Animals

\begin{tabular}{|c|c|c|c|c|c|}
\hline Parameter & $\begin{array}{l}\text { Group-I } \\
\text { (Control) }\end{array}$ & $\begin{array}{c}\text { Group-II } \\
\text { (Tumour induced) }\end{array}$ & $\begin{array}{l}\text { Group-III } \\
\text { (Tumour induced + } \\
\text { post KA treated) }\end{array}$ & $\begin{array}{l}\text { Group-IV } \\
\text { (Tumour induced }+ \\
\text { simultaneous KA treated) }\end{array}$ & $\begin{array}{c}\text { Group-V } \\
\text { (Drug control) }\end{array}$ \\
\hline \multicolumn{6}{|c|}{ Plasma } \\
\hline $\begin{array}{l}\text { GSH } \\
(\mu \mathrm{g} / \mathrm{mg} \text { protein })\end{array}$ & $1.79 \pm 0.12$ & $\left.1.12 \pm 0.09^{*}, a\right)$ & $1.45 \pm 0.10^{*, b)}$ & $1.63 \pm 0.13^{*, b, c)}$ & $1.79 \pm 0.11^{a), \mathrm{NS}}$ \\
\hline $\begin{array}{l}\text { Vit. C } \\
(\mathrm{mg} / \mathrm{dl})\end{array}$ & $2.17 \pm 0.18$ & $\left.1.04 \pm 0.08^{*}, a\right)$ & $1.61 \pm 0.13^{*, b)}$ & $2.03 \pm 0.16^{*, b, c)}$ & $2.19 \pm 0.20^{a), \mathrm{NS}}$ \\
\hline $\begin{array}{l}\text { Vit. E } \\
(\mathrm{mg} / \mathrm{dl})\end{array}$ & $3.29 \pm 0.30$ & $\left.2.03 \pm 0.15^{*, a}\right)$ & $2.61 \pm 0.21^{*, b)}$ & $\left.3.16 \pm 0.24^{*}, b, c\right)$ & $3.30 \pm 0.31^{a), \mathrm{NS}}$ \\
\hline \multicolumn{6}{|c|}{ Breast } \\
\hline $\begin{array}{l}\text { GSH } \\
(\mu \mathrm{g} / \mathrm{mg} \text { protein })\end{array}$ & $50.19 \pm 4.46$ & $\left.23.27 \pm 2.2^{*}, a\right)$ & $36.73 \pm 3.3^{*, b)}$ & $\left.49.59 \pm 4.44^{*}, b, c\right)$ & $50.5 \pm 4.23^{a), \mathrm{NS}}$ \\
\hline $\begin{array}{l}\text { Vit. C } \\
\text { (mg/g wet tissue) }\end{array}$ & $9.17 \pm 0.88$ & $\left.2.91 \pm 0.26^{*, a}\right)$ & $\left.6.03 \pm 0.57^{*}, b\right)$ & $8.77 \pm 0.80^{*, b, c)}$ & $9.19 \pm 0.86^{a), \mathrm{NS}}$ \\
\hline $\begin{array}{l}\text { Vit. E } \\
\text { (mg/g wet tissue) }\end{array}$ & $8.15 \pm 0.79$ & $2.27 \pm 0.17^{*, a)}$ & $5.21 \pm 0.46^{*, b)}$ & $7.97 \pm 0.75^{*, b, c)}$ & $8.13 \pm 0.77^{a), \mathrm{NS}}$ \\
\hline
\end{tabular}

The values are expressed as mean \pm S.D. of six animals. Comparisons were made between: $a$ ) When compared with control animals. $b$ ) When compared with mammary carcinoma induced animals. $c$ ) When compared with mammary carcinoma + post KA treated. * denotes significance at the level of $p<0.05$. NS denotes non-significance at the level of $p<0.05$.

cells against damage caused by reactive oxygen metabolites. ${ }^{46)}$ The reduction in antioxidants level indicates the inability of these defense systems to scavenge the enormous free radical produced during mammary carcinoma development.

Non-enzymic antioxidants like GSH, Vitamin E and Vitamin $\mathrm{C}$ have shown to ameliorate adverse effects associated with free radical damage to nor- mal levels in cancer therapy and to reduce the recurrence of breast cancer. ${ }^{47)}$ Lowered vitamin $\mathrm{E}$ and vitamin $\mathrm{C}$ are not sufficient to counter higher reactive oxygen species produced in breast cancer. This may lead to oxidative stress, leading to cellular and molecular damage thereby resulting in cell proliferation and malignant conversion ${ }^{45)}$ (Hussain et al., 2001). GSH serves as substrate for GPx, an enzyme 
Table 8. Effect of KA on the Levels of ROS in the Hemolysate of Control and Experimental Animals

\begin{tabular}{|c|c|c|c|c|c|}
\hline Parameters & $\begin{array}{l}\text { Group I } \\
\text { (Control) }\end{array}$ & $\begin{array}{c}\text { Group II } \\
\text { (Tumour induced) }\end{array}$ & $\begin{array}{l}\text { Group III } \\
\text { (Tumour induced + } \\
\text { post KA treated) }\end{array}$ & $\begin{array}{l}\text { Group IV } \\
\text { (Tumour induced }+ \\
\text { simultaneous KA treated) }\end{array}$ & $\begin{array}{c}\text { Group V } \\
\text { (Control + KA) }\end{array}$ \\
\hline $\begin{array}{l}\text { Superoxide radical } \\
\text { (nmoles } \mathrm{NB} / 10 \mathrm{~min} \\
\left./ 10^{12} \text { cells } / \mathrm{hr}\right)\end{array}$ & $55.31 \pm 4.9$ & $127.40 \pm 11.5^{*, a)}$ & $68.11 \pm 6.1^{*, b)}$ & $\left.97.32 \pm 9.2^{*}, b, c\right)$ & $54.96 \pm 5.0^{a), \mathrm{NS}}$ \\
\hline $\begin{array}{l}\text { Hydroxyl radical } \\
\left.\text { (nmoles } / 10^{12} \text { cells } / \mathrm{hr}\right)\end{array}$ & $11.45 \pm 0.7$ & $38.31 \pm 3.1^{*, a)}$ & $15.33 \pm 1.1^{*, b)}$ & $27.14 \pm 2.1^{*, b, c)}$ & $11.81 \pm 0.7^{a), \mathrm{NS}}$ \\
\hline $\begin{array}{l}\mathrm{H}_{2} \mathrm{O}_{2} \\
\left(\mu \text { moles } / 10^{12} \text { cells }\right)\end{array}$ & $64.27 \pm 5.9$ & $176.59 \pm 16.8^{*, a)}$ & $\left.93.54 \pm 8.5^{*}, b\right)$ & $142.62 \pm 13.4^{*, b, c)}$ & $63.97 \pm 5.8^{a), \mathrm{NS}}$ \\
\hline
\end{tabular}

that function to remove $\mathrm{H}_{2} \mathrm{O}_{2}$, which oxidizes it to form GSSG. Vitamin $\mathrm{E}$ has an operative role in cancer. It is an excellent lipid soluble chain breaking antioxidant in the presence of the co-operative antioxidants like vitamin C, Carotenoids, etc ${ }^{48)}$ Vitamin E prevents lipid peroxidation and this prevents membrane damage and modification of low-density lipoproteins. ${ }^{49}$

Upon administration of Kalpaamruthaa to mammary carcinoma animals, the activities of enzymic antioxidants and non-enzymic antioxidants were increased when compared to the diseased animals. This may be due to the action of flavonoids, isoflavonoids and ascorbic acid present in the drug. Flavonoids and isoflavonoids have potent antioxidant activity relavent to cancer. ${ }^{50,51)}$ Glycoside linked flavonoids are responsible for antioxidant effects. ${ }^{43)}$ Isoflavonoids play an important role in prevention of breast cancer, prostrate cancer and atherosclerosis. ${ }^{52)}$ This accounts for the anti tumour property of the drug through modulating the ROS and lipid peroxidation.

The above experimental results obtained indicate that the drug has definite curative and protective efficacy against mammary carcinoma. Due to its potent therapeutic property and non-toxic nature upto high doses, it may be considered to be used as a safe energetic pharmacological drug in the field of cancer therapy without much complication. Simultaneous KA treated animals showed greater response to KA, when compared to post KA treated animals. This can possibly be attributed to the therapeutic efficacy of KA in curtailing tumour initiation and progression, a prophylactic property.

\section{REFERENCES}

1) Behrend, L., Henderson, G. and Zwacka, R. M. (2003) Reactive oxygen species in oncogenic transformation. Biochem. Soc. Trans., 31, 1441-1444.

2) Hristozov, D., Gadjeva, V., Vlaykova, T. and Dimitrov, G. (2001) Evaluation of oxidative stress in patients with cancer. Arch. Physiol. Biochem., 109, 331-336.

3) Fang, Y.-Z., Sheng, Y. and Guoyao, W. (2002) Free radicals, antioxidants and nutrition. Nutrition, $\mathbf{1 8}$, 872-879.

4) Kumaraguruparan, R., Subapriya, R., Kabalimoorthy, J. and Nagini, S. (2002) Antioxidant profile in the circulation of patients with fibroadenoma and adenocarcinoma of the breast. Clin. Biochem., 35, 275279.

5) Tiwari, A. K. (2004) Antioxidants; new-generation therapeutic base for treatment of polygenic disorders. Curr. Sci., 86, 1092-1103.

6) Polat, F. M., Taysi, S., Gul, M., Cikman, O., Yilmaz, I. and Bakan, E. (2002) Oxidant/antioxidant status in blood of patients with malignant breast tumour and benign breast disease. Cell Biochem. Funct., 20, 327-331.

7) Abou Ghalia, A. H. and Fouad, I. M. (2000) Glutathione and its metabolizing enzymes in patients with different benign and malignant diseases. Clin. Biochem., 33, 657-662.

8) Scot, M. D., Lubin, B. H., Linzuo and Kuypers F. A. (1991) Erythrocyte defense against hydrogen peroxide. Preeminent importance of catalase. J. Lab. Clin. Med., 118, 7-16.

9) Diplock, A. T. (1991) Antioxidant nutrients and disease prevention: an overview. Am. J. Clin. Nutr., 53, 189-193.

10) Veena, K., Shanthi, P. and Sachdanandam, P. (2006) Anticancer effect of Kalpaamruthaa on mammary carcinoma in rats with reference to glycoprotein 
components, lysosomal and marker enzymes. Biol. Pharm. Bull., 29, 565-569.

11) Kirthikar, K. R. and Basu, B. D. (1933) Indian Medicinal Plants (2nd edn) (Basu, L. M. Ed.), M/s Bishen Sigh, Mahendra Palsingh Allahabad, vol. 1, pp. 667-670.

12) Vijayalakshmi, T., Muthulakshmi, V. and Sachdanandam, P. (1996) Effect of milk extract of Semecarpus anacardium nut on adjuvant arthritis. A dose dependent study in Wistar albino rats. Gen. Pharmacol., 27, 1223-1226.

13) Sujatha, V. and Sachdanandam, P. (2000) Protective effect of nut milk Semecarpus anacardium Linn. Extract against mammary carcinoma. National Seminar on Frontiers of Research and Development in Medicinal Plant sciences, Lucknow, J. Med. Aromat. Plant Sci., 22, 1-10.

14) Arathi, G. and Sachdanandam, P. (2003) Therapeutic effect of Semecarpus anacardium Linn. nut milk extract on carbohydrate metabolizing and mitochondrial TCA cycle and respiratory chain enzymes in mammary carcinoma rats. J. Pharm. Pharmacol., 55, 1283-1290.

15) Vijayalakshmi, T., Muthulakshmi, V. and Sachdanandam, P. (1997) Effect of milk extract of Semecarpus anacardium nuts on glycohydrolases and lysosomal stability in adjuvant arthritis in rats. J. Ethnopharmacol., 58, 1-8.

16) Ramprasath, V. R., Shanthi, P. and Sachdanandam, P. (2005) Semecarpus anacardium Linn. nut milk extract, an indigenous drug preparation, modulates reactive oxygen/nitrogen species levels and antioxidative system in adjuvant arthritic rats. Mol. Cell. Biochem., 276, 97-104.

17) Premalatha, B., Muthulakshmi, V., Vijayalakshmi, T. and Sachdanandam, P. (1997) Productive role of Serankottai nei, a Siddha preparation, on cell membranes, aflatoxin B1 induced hepatocellular carcinoma bearing rats. Indian Drugs, 34, 385-389.

18) Calixto, J. B., Santos, A. R., Cechinel Filho, V. and Yunes, R. A. (1998) A review of the plants of the genus Phyllanthus: Their chemistry, pharmacology, and therapeutic potential. Med. Res. Rev., 18, 225258.

19) Ihantola-Vormisto, A., Summanen, J., Kankaaranta, H., Vuorela, H., Asmawi, Z. M. and Moilanen, E. (1997) Anti-inflammatory activity of extracts from leaves of Phyllanthus emblic Sujatha a. Planta Med., 63, 518-524.

20) Khan, M. T., Martello, D., Bianchi, N., Jabbar, S., Choudhuri, M. S., Datta, B. K. and Gambari, R. (2002). Identification of pyrogallol as an antiproliferative compoundpresent in extracts from the medicinal plant Emblica officinalis: Effects on in vitro cell growth of human tumor cell lines. Intl.
J. Onc., 20, 187-192.

21) Zhang, T., Chen, X., Qu, L., Wu, J., Cui, R. and Zhao. Y. (2004) Chrysin and its phosphate ester inhibit cell proliferation and induce apoptosis in Hela cells. Bioorg. Med. Chem., 12, 6097-6105.

22) Frei, B. (1994) Reactive oxygen species and antioxidant vitamins: mechanisms of action. Am. J. Med., 97, 5S-13S.

23) Dodge, J. T., Carolyn, M. and Donald, J. M. (1963) Preparation and chemical characteristics of haemoglobin-free ghosts of human erythrocytes. Arch. Biochem. Biophys., 100, 119-130.

24) Devasagayam, T. P. and Tarachand, U. (1987) Decreased lipid peroxidation in the rat kidney during gestation. Biochem. Biophys. Res. Commun., 145, 469-474.

25) Yagi, K. (1976) Simple fluorimetric assay for lipoperoxide in blood plasma. Biochem. Med., 15, 212-216.

26) Marklund, S. and Marklund, G. (1974) Involvement of superoxide anion radical in the auto-oxidation of pyrogallol and a convenient assay for superoxide dismutase. Eur. J. Biochem., 47, 469-471.

27) Sinha, A. K. (1972) Colorimetric assay of catalase. Anal. Biochem., 47, 380-390.

28) Rotruck, J. T., Pope, A. L., Ganther, H. E., Swanson, A. B., Hafeman, D. G. and Hoekstra, W. G. (1973) Selenium, biochemical role as a component of glutathione peroxidase purification and assay. Science, 179, 588-590.

29) Habig, W. H., Pabst, M. J. and Jakoby, W. B. (1974) Glutathione-S-transferases. The first enzymatic step in mercapturic acid formation. J. Biol. Chem., 249, 7130-7139.

30) Moron, M. S., Depierre, J. W. and Mannervik, B. (1979) Levels of glutathione, glutathione reductase and glutathione-S-transferase activities in rat lung and liver. Biochim. Biophys. Acta., 582, 67-78.

31) Quaife, M. L. and Dju, M. Y. (1948) Chemical estimation of vitamin $\mathrm{E}$ in tissues and the $\alpha$-tocopherol content of normal tissues. J. Biol. Chem., 180, 263272.

32) Baker, A. F. and Frank, G. (1951) Estimation of vitamin E in tissues. In Dunnschict-chromatographic in laboratorium (Stahl, R., Ed), Springer-verlag, Berlin, pp. 41-52.

33) Desai, I. D. (1984) Vitamin E analysis methods for animal tissues. Methods Enzymol., 105, 138-147.

34) Omaye, S. T., Turabull, J. D. and Sauberlich, H. E. (1979) Selected methods for the determination of ascorbic acid in animal cells, tissues and fluids. Methods Enzymol., 62, 1-11.

35) Lowry, O. H., Rosenbrough, N. J., Farr, A. L. and Randall, R. J. (1951) Protein measurement with the Folin phenol reagent. J. Biol. Chem., 193, 265-275. 
36) Gutteridge, J. M. (1981) Thiobarbituric acid-reactivity following iron-dependent free-radical damage to amino acids and carbohydrates. FEBS Lett., 128, 343-346.

37) Nishikimi, M., Appaji, N. and Yagi, K. (1972) The occurance of superoxide anion in the reaction of reduced phenazine methosulphate and molecular oxygen. Biochem. Biophys. Res. Commun., 46, 849-854.

38) Wolff, S. P. (1994) Ferrous ion oxidation in presence of ferric ion indicator xylenol orange for measurement of hydroperoxides. Methods Enzymol., 23, 180-189.

39) Tessitore, L., Costelli, P. and Baccino M. F. (1994) Pharmacological interference with tissue hypercatabolism in tumour-bearing rats. Biochem. J., 299, 71-78.

40) Pain, P., Dessi, S., Rao, K. N., et al. (1984) Cholertrol synthesis in lead induced liver hyperplasia in wistar rats. Toxicol. Pathol., 12, 162-166.

41) Hollman, P. C. and Katan, M. B. (1997) Absorption, Metabolism and Health effects of dietary flavonoids in man. Biomed. Pharmacother, 81, 305310.

42) Ray, G. and Husain, S. A. (2002) Oxidants, antioxidants and carcinogenesis. Indian. J. Exp. Biol., 40, 1213-1232.

43) Chakraborty, S., Roy, M., Taraphdar, A. K and Bhattacharya, R. K. (2004) Cytotoxic effect of root extract of Tiliacora racemosa and oil of Semecarpus anacardium nut in human tumour cells. Phytother. Res., 18, 595-600.

44) Khanzode, S. S., Muddeshwar, M. G., Khanzode, S. D. and Dakhale, G. N. (2004) Antioxidant enzymes and lipid peroxidation in different stages of breast cancer. Free Radical Res., 38, 81-85.
45) Hussain, S. P., Hofseth, L. J. and Harris, C. C. (2001) Tumor suppressor genes: at the crossroads of molecular carcinogenesis, molecular epidemiology and human risk assessment. Lung Cancer, Suppl 2, S7S15.

46) Ray, G., Batra, S., Shukla, N. K., Deo, S., Raina, V., Ashok, S. and Husain, S. A. (2000) Lipid peroxidation, free radical production and antioxidant status in breast cancer. Breast Cancer Res Treat., 59, 163-170.

47) Borek, C. (2004) Dietary antioxidants and human cancer. Integr. Cancer Ther., 3, 333-341.

48) Burton, P. B., Hogben, C. E., Joannou, C. L., Clark, A. G., Hsuan, J. J., Totty, N. F., Sorensen, C., Evans, R. W. and Tynan, M. J. (1994) Heart fatty acid binding protein is a novel regulator of cardiac myocyte hypertrophy. Biochem. Biophys. Res. Commun., 205, 1822-1828.

49) Stahl, W. and Sies, H. (1997) Antioxidant defense: vitamins E and C and carotenoids. Diabetes, Suppl 2, S14-S18.

50) Cesquini, M., Torsoni, M. A., Stoppa, G. R. and Ogo, S. H. (2003) t-BOOH-induced oxidative damage in sickle red blood cells and the role of flavonoids. Biomed. Pharmacother., 57, 124-129.

51) Liu, L. Z., Fang, J., Zhou, Q., Hu, X., Shi, X. and Jiang, B. H. (2005) Apigenin inhibits expression of vascular endothelial growth factor and angiogenesis in human lung cancer cells: implication of chemoprevention of lung cancer. Mol. Pharmacol., 68, 635-643.

52) Guo, Q., Rimbach, G., Moini, H., Weber, S. and Packer, L. (2002) ESR and cell culture studies on free radical-scavenging and antioxidant activities of isoflavonoids. Toxicology, 179, 171-180. 